\title{
Implementation of The JKN Programs on The Community Health Center at Level 1 (Descriptive study of the implementation of the JKN program at the Pucang Sewu Health Center, Gubeng District, Surabaya City)
}

\author{
Sri Roekminiati ${ }^{1}$, Sapto Pramono ${ }^{2}$, Nihayatus Sholichah ${ }^{3}$, Ika Devy Pramudiana ${ }^{4}$ \\ \{sri.roekminiati@unitomo.ac.id ${ }^{1}$, sapto.pramono@unitomo.ac.id ${ }^{2}$, \\ Nihayatus.sholichahs@unitomo.ac.id ${ }^{3}$ \} \\ 1,2,3,4 Faculty of Administrative Sciences, Dr. Soetomo University, Indonesia
}

\begin{abstract}
The JKN-era Community Health Center (Puskesmas) is a health service that organizes public health efforts and first-rate individual health efforts. In addition, Puskesmas must be able to provide 155 types of health diagnostics to support the implementation of JKN. In fact, the obstacles and weaknesses of the JKN program are found in the Puskesmas. What eventually came to the clinic or a private doctor who received the facilities of JKN. The purpose of this study is to describe, analyze and interpret the implementation of the JKN program policy. This type of search uses a qualitative description search method. The results showed: The communication facilities used to introduce the JKN program were realized by placing large banners near the Puskesmas, streamers, and signs in the waiting/queue room and organizing socialization. in the form of direct advice given by the doctors of the clinic; Resources include; Human resources; Infrastructure; Finance has fulfilled the ideal conditions for achieving quality service. The commitments made by the relevant institutions to implement the JKN program are so ambitious that harmonious relationships are established and synergy between related institutions to provide quality services. In addition, the success of the Pucang Sewu Community Health Center in providing patient services with the JKN program is also due to the service status that has enabled the ISO. In this study, the researcher made suggestions, it is necessary to continue to add and improve the quality of resources. It is expected that all future health center services will be ISO 9001-2000 compliant and continue to innovate in service by adapting the needs of the people in their area.
\end{abstract}

Keywords: Public policy implementation, community health center, guarantee.

\section{Introduction}

To create a healthy country, the government has put in place a program called National Health Insurance (JKN). In the JKN program, health services are delivered in stages, starting with primary, secondary and tertiary health care facilities. The sick population must first access primary health services, namely community health centers (Puskesmas), family physicians and clinics. If primary health care jurisdiction is unable to treat a case, patients will be referred to secondary health services, ie hospitals in the area. The Puskesmas will also work in partnership with general practitioners and Pratama clinics, especially to promote disease prevention. 
Definition of Puskesmas according to Puskesmas work guidelines DEPKES-RI is a functional health organizational unit that is the center of community health development. It also promotes community participation in addition to providing comprehensive and integrated services to the community in its workspace in the form of core activities [1]. Security System Act No. 40 of 2004 for Puskesmas as the first and largest unit of health services in the health services system, the health services system must make health care and some health efforts are adapted to local conditions, needs, requirements, capacities and innovations and policies. Puskesmas participate in comprehensive and integrated health efforts to improve, prevent, cure and heal, with the necessary support efforts. The availability of resources, both in quality and quantity, significantly affects health services. In addition, Puskesmas must be able to provide 155 types of health diagnostics to support the implementation of JKN. Referral to the health center is one of the mandatory requirements for patients who wish to access JKN at the hospital. Of course, this is a request that can not be considered light and requires a significant commitment to providing the best service.

The implementation of the JKN program at the beginning of the implementation encountered several obstacles, including the fact that not all residents, distribution of health services, variable quality of health services, referral systems and suboptimal payments. Inequality in the availability of health facilities, health human resources and a wide variety of geographic conditions raises the risk of widening health inequities between community groups [2].

Regarding the resources of the device, quality, and quantity, including the limited number and distribution of physicians, and efforts to increase the capacity of the capitation funds, are still not optimal even if the number of training increases, especially in the health center with low capitation funds. The limited number of physicians compared to JKN participants resulted in a high proportion of physicians, which can certainly reduce the quality of services, as doctors control their abilities, whereas in the health center $s$ with a ratio of physicians / small participants, the doctors have plenty of time to examine patients [3].

The number of inpatient and outpatient health centers in East Java Province is 963 (Source: http://www.depkes.go.id, accessed 15 July 2019). Compared with the number of existing health centers and the number of residents served in the province of East Java is 39,292,973. (Source: https: //jatim.bps.go.id, accessed July 15, 2019). While the ideal size of a health center serves 25,000 to 30,000 populations, this indicates that the existence of the health center in the province of East Java is still lacking. Ideally, the minimum number of a health center in the province of East Java is \pm 1500 pieces.

The Pucang Sewu health center in Surabaya, with an auxiliary health center in Baratajaya, has served up to 53,058 people, according to the researchers. The researchers wanted to conduct research at the Pucang Sewu Health Center, fearing that the JKN program services described above have not been proven. In 2014, the Pucang Sewu Health Center won the 1st FKTP Champion Award, which allowed it to provide quality services at the Jamboree Primary Services Regional Division organized by health for East Java, BPJS. In addition, the Pucang Sewu Health Center is a Puskesmas that has used the ISO 9001: 2008 service standards. This is what the researchers say is interesting to deepen the implementation of the JKN program in the center. Pucang Sewu Health Center, Gubeng District, in Surabaya City as a First Level Health Center (FKTP). 


\section{Theory}

\subsection{Public policy}

In the book, Public Policies: Theory and Process [4], the term "political" or "political" is generally used to refer to the behavior of an actor (eg an official, a group or a government). institution) or a number of actors in a particular field of activity. The definition of a policy like this one can be used and is relatively adequate for the purposes of ordinary discussions, but becomes insufficient for more scientific and systematic discussions regarding public policy analysis. According to (Thoha) cited by Ramdhani [5], giving an explanation of public policy following the formulation of a government. From this point of view, public policy is better understood as what is done by the government than by the process of obtaining results. At the same time, according to Nugroho quoted by Kurnia [6], public policy in the international literature is described as public policy, namely the rules of shared life to which one must obey and who apply to compel all its citizens.

\subsection{Model of the policy implementation process}

Conceptually, the approach to implementation studies can be carried out from several perspectives or models, including the based approach: failure analysis, rational model ("descendant"), "bottom-up" critique of the model "Descendant" and "hybrid" theory [7]. Considering that the culture of policy implementation in Indonesia is adopting a top-down model, and in accordance with the problems and objectives of this paper, the literature review and the theoretical framework of the process model of Policy implementation that will be described below are more dominant in the rational model.

In the development of the application of rational models, several studies conducted to explain the factors or determinants of the success of policy implementation have made progress in terms of progress. Initially, the implementation studies tended to focus on the characteristics of the Grindle bureaucracy in 1980, cited by Prameswari, Y. P. [8]. Implementation studies in this perspective, for example, led by Edward III, identify 4 (four) determinants that will influence the process and outcomes of policy implementation, namely: (1) communication (2) bureaucratic structure, 3) resources, and (4) disposition (disposition) [9].

Another model of policy implementation according to Donald Van Meter and Carl Van Horn, cited by Wirasandi [10], is descendant. This implementation model includes six variables, namely policy norms, and objectives, resources, organizational characteristics, communication between related organizations and implementation activities, implementation of attitudes and the environment.

\subsection{Public service provider}

According to the institutions that organize them, public service providers can be divided into two: public institutions and private/private institutions (Ratminto and Winarsih, 2005: 812), cited by Hamid, A. A. [11]. Public services provided by the private sector are all goods and/or public services provided by private institutions. Private hospitals, private universities (PTS) or private transport companies are private institutions that provide public goods/services. Public services provided by public institutions all consist of the provision of public goods/services provided by the government, including the village government. This public service can be both primary and secondary. 


\subsection{National Health Insurance Program}

The JKN program is a form of health reform aimed at solving the problem of fragmentation and distribution of health insurance. This problem occurs in the Community Health Insurance Scheme (Jamkesmas) and Regional Health Insurance (Jamkesda), resulting in uncontrolled health costs and excellent quality of service. National Health Insurance (JKN) is part of the National Social Security Scheme (SJSN), which applies through a compulsory health insurance scheme [12].

\subsection{Community Health Centers}

The Community Health Center (Puskesmas) is one of Indonesia's largest public health centers. Puskesmas is an official district / city technical implementation unit responsible for implementing health development in a work area [13]. The definition of puskesmas is a functional functional unit functioning as a health development center, community participation center in the health sector and health service center. The first level is to conduct its activities in a comprehensive and integrated way in a community located in a certain region [12].

\section{Research methods}

This search is a direction to effort or answer to a numerical answer, as well as social, as well as social and the problem of research. In principle, this study uses a qualitative approach. With a qualitative approach, one should be able to produce a detailed description of the words, scriptures and/or things that can be observed from an individual, a group, society, an organization/community in a context-specific from a holistic approach., global and holistic perspective. The data analysis method proposed by [14] which indicates in the qualitative research, the analysis of the data is carried out through three (three) lines of activities which proceed simultaneously, to the condensation, the presentation, and the conclusion.

\section{Discussion}

\subsection{Implementation of the JKN Program at the Pucang Sewu Health Center}

The following are the results of the research and discussions related to 4 (four) variables that influence the implementation of the JKN program at the Surabaya Pucang Sewu Health Center, namely: 1) communication, 2) resources, 3) provision and 4) the bureaucratic structure

\subsubsection{Communication}

In the implementation of the JKN communication program, this program uses various print and electronic media. Recognizing that this program is a national program for delivering messages to the public, the central government, provincial government, district / city governments, hospitals and health centers complete the information through print media such as: newspapers (Jawa Pos, Kompas, etc.), banners in front of the hospital, Puskesmas, billboards on strategic roads (for example, Jemursari Dolog Corner), brochures, leaflets and electronic media ( television) performed by artist Ria Irawan. In addition, communication also involves socializing 


\subsubsection{Resource}

The resources owned by the Pucang Sewu Health Center can be described as follows:

\section{a. Human Resources (HR)}

The health center of HR consists of medical staff and non-medical staff. Based on existing data sources of human resources belonging to the Pucang Sewu Community Health Center, as seen in the regulation of the Minister of Health of the Republic of Indonesia No. 75 of 2014 regarding Article 16 of the community health already fulfills the requirements as an ideal health center.

\section{b. Infrastructure facilities}

If you refer to the regulation of the Minister of Health of the Republic of Indonesia No. 75 of 2014 regarding Article 13 of the Community Health Center, the facilities of the Surabaya Pucang Sewu Health Center met these requirements because this health center is ideal because there is Batra Equipment, Children's Growth Arena and Toga Park

\section{c. Financial}

According to the regulation of the Minister of Health of the Republic of Indonesia, number 75 of 2014, article 2014, the financing of the health center of Pucang Sewu comes from 1). Regional Revenue and Expenditure Budget (APBD); 2) State Revenue and Expenditure Budget (APBN) and 3). Other legal and non-binding sources.

\section{d. In position}

The provision concerns the will of the performers to apply the policy. The commitment to implement the JKN program is reflected in various activities carried out by the central government, even the regions, notably through Monitoring and the evaluation (Monev) and Jamboree of the basic services of the regional division VII.

\section{e. Bureaucratic structure}

In the implementation of the JKN program at the Pucang Sewu Health Center, the relations between the organizing institute of the JKN program, namely the organization organizing the health insurance (BPJS), the local government, the office of the health SKPD and the hospital resort in collaboration with BPJS maintain a harmonious and synergistic relationship with producing quality services.

\subsection{Service strategies developed by the Pucang Sewu Health Center as part of the implementation of the JKN program}

Having the health center ISO 9001: 2008 holder status since 2008 is indeed not so difficult for the Pucang Sewu Health Center to provide quality services to the community, especially patients participating in the BPJS program, as they meet international requirements for service quality assurance management. they produce. Medical staff and paramedics are also accredited and licensed to practice. The Puskesmas, as the spearhead of health providers, are responsible for the implementation and comprehensive and integrated development of health in its work area. 
The health center to obtain ISO 9001, there are four standards, namely the first ISO standard itself, the second government regulation standardized in this case is consistent with Kepmenpan number 63 of 2003 regarding the guidelines for the public service [14], the three codes of ethics. which are determined by the professional organizations and those of the fourth standard of the user or the patient. In addition to these four standards, another requirement is the need for innovation. According to this researcher in innovation, the service presented the Pucang Sewu Health Center as the best FKTP I at the Jamboree of Primary Services. Regional Division VII was organized by the BPJS

\section{Conclusion}

The success of the Pucang Sewu Health Center in the implementation of the JKN program in Puskesmas has been relatively successful and has resulted in the delivery of quality services. Excellent service innovations, such as seniors' services, traditional medicine, early childhood poly-detection, and independent pregnant women, greatly contribute to the quality of services provided. This can be used as a service model for other the health center that adapts the local content in their respective health center zones.

Practical tips that researchers have conveyed for the perfect implementation of the JKN program policy, especially in Puskesmas as FKTP, namely:

a. The relatively new JKN policy should allow all concerned institutions to always pay attention to the various obstacles encountered on the ground, including the health center as the spearhead of the service, which is sometimes the target of public anger that is sometimes caused by ignorance of rights and freedoms. obligations of BPJS participants

b. In examining the growing trend of visits to the health center that continues to require the best service, the health center should be better supported by adequate human resources, infrastructure and financial resources from the central and regional governments.

To improve the quality of health, this policy can be pursued with several recommendations, including:

a. It is considered necessary that all the agencies involved organizing continuous socialization, and more importantly, the health center and hospitals so that the public knows its rights and obligations as holders of the BPJS card. This is done to avoid various types of criticism from people dissatisfied with the services provided by the health center and hospitals.

b. It is expected that all levels of JKN health facilities will be Primary Health Care (Puskesmas, Clinic, Family Physicians), Secondary (Type B, C), Tertiary (Type A hospitals) that have a high mortality rate. commitment to provide services of this quality in accordance with the regulations in force.

c. As this is a national program, it is considered necessary to continue to add and improve the quality of resources, including human resources, health infrastructure in health centers and hospitals led by the central government, regional governments, and other relevant institutions to be able to provide quality services.

\section{References}

[1] Radito, “Analis Pengaruh Kualitas ...," Ilmu Manaj., vol. 11, no. 2, pp. 1-26, 2014.

[2] M. Saputra, L. Marlinae, F. Rahman, and D. Rosadi, "Program Jaminan Kesehatan Nasional Dari Aspek Sumber Daya Manusia Pelaksana Pelayanan Kesehatan,” J. Kesehat. Masy., vol. 11, no. 1, p. 32, 2015.

[3] A. G. Hasan and W. B. B. Adisasmito, "Analisis Kebijakan Pemanfaatan Dana 
Kapitasi JKN pada FKTP Puskesmas di Kabupaten Bogor Tahun 2016," J. Kebijak. Kesehat. Indones., vol. 6, no. 3, p. 127, 2017.

[4] B. Winarno, Kebijakan Publik: Teori dan Proses. Yogyakarta: Media Pressindo, 2007.

[5] A. Ramdhani, "Konsep Umum Pelaksaan Kebijakan Publik," J. Publik, vol. 11, no. 1, pp. 1-12, 2017.

[6] I. Program, B. M. Dewe, and K. Dm, "Implementasi Program 'Berkas Mlaku Dewe' Kurnia DM dan Nihayatus S,” vol. 2, no. 2, pp. 237-254, 2018.

[7] A. Rakhmatsyah, M. Hasanuddin, and M. Tahir, "Dampak Kebijakan Ruang Terbuka Hijau Di Kota Makassar,” Adm. Publik, vol. 1, no. 2, pp. 126-138, 2015.

[8] Y. P. Prameswari, "Waterfront city development di kawasan sempadan sungai: Studi kasus Sungai Wiso dan Kanal, Jepara,” J. Ilm. Ilmu Pemerintah., vol. 3, no. 1, p. 51, 2018.

[9] I. A. Sirajuddin, "Implementasi Kebijakan Pemerintah Daerah Dalam Pelayanan Publik Dasar Bidang Sosial Di Kota Makassar,” J. Ilm. Ilmu Adm. Publik, vol. 4, no. 1, pp. 114, 2016.

[10] P. K. Makassar, Implementasi undang-undang nomor 5 tahun 2014 dalam pengembangan kompetensi aparatur sipil negara di dinas pendidikan kota makassar. 2018.

[11] A. Hamid, "Otonomi Daerah dan Kualitas Pelayanan Publik," Bul. Pengawas., vol. 3, no. 30 dan 31, pp. 535-546, 2001.

[12] H. A. Khariza, "Program Jaminan Kesehatan Nasional: Studi Deskriptif Tentang Faktor-Faktor Yang Dapat Mempengaruhi Keberhasilan Implementasi Program Jaminan Kesehatan Nasional," J. Kebijak. dan Manaj. Publik, vol. 3, no. 1, pp. 1-7, 2015.

[13] Http://www.depkes.go.id, "No Title."

[14] Y. Ariswati, Kepala Sekolah Sebagai Contoh. 2017. 